\title{
Effect of Bacillus safensis NBRC 100820 isolated from cotton plant against the spiny bollworm, Earias insulana (Boisduval)
}

\author{
Ali Ahmed El-Sayed ${ }^{1 *}$ (C) Mohammed Farouk Ghaly ${ }^{2}$ and Ahmed Adel Amer ${ }^{2}$
}

\begin{abstract}
Background: Toxic effect of some local bacterial isolates, isolated from the Egyptian cotton plant (Gossypium barbadance L.), on larvae of the spiny bollworm (SBW), Earias insulana (Boisduval) (Lepidoptera: Nolidae) was studied as well as the biological effects of the most toxic isolate.

Results: Bacillus safensis NBRC 100820 had the most toxic effect on the SBW larvae compared to other isolates. Larval mortality percentages were 100, 90, 50, 50 and 30\% for newly hatched, 3, 5, 7 and 10-day's old larvae, respectively, after 2 days from treatment. Moreover, B. safensis NBRC 100820 caused latent effects on different stages of SBW. It decreased the larval and pupal weight, percentages of adult emergence and hatchability as well as number of deposited eggs/female more than the control. Using 16s rRNA confirmed the identification of B. safensis NBRC 100820 and its accession number is MW281809.
\end{abstract}

Conclusions: Use of B. safensis NBRC 100820 can be recommended for biological control of E. insulana. Further field studies are needed.

Keywords: Earias insulana, Bacillus safensis, Gossypium barbadance, Biological control

\section{Background}

Spiny bollworm (SBW), Earias insulana (Boisduval) (Nolidae: Lepidoptera) has been recorded as one of the most destructive insect pests, responsible for great economic losses of cotton yield in Egypt (Nada et al. 2010). Meanwhile, insecticides are considered the main protocol used for controlling the cotton pests due to their high efficacy (Wang et al. 2012). On the other hand, using of insecticides in cotton field has caused many problems such as environmental pollution, insecticides-resistance, and harmful effects to natural enemies (Yongqiang et al. 2016). Biological control represents one of the most effective choice to control many insect pests. The entomopathogenic bacterial strains, especially species

\footnotetext{
*Correspondence: aliahmed_2020@yahoo.com

${ }^{1}$ Plant Protection Research Institute, Agricultural Research Center, Dokki,

Egypt

Full list of author information is available at the end of the article
}

belonging to the genus Bacillus, are one of the most effective groups of entomopathogenic bioagents (Glare and O'Callagan 2006).

Bacillus safensis originally isolated from spacecraft surfaces in California and Florida, USA (Satomi et al. 2006). Moreover, this species was currently isolated from surface soil (Ishag et al. 2016) and plants (Wahla et al. 2019). B. safensis, is a gram-positive bacterium, spore forming, aerobic, rod shaped and motile (Satomi et al. 2006). In addition, it can grow within a temperature range of $10-50{ }^{\circ} \mathrm{C}$ and $\mathrm{pH}$ range of $4.0-9.0$ (Roohi et al. 2014). Bacillus thuringiensis dominates the insect pest-control agents' market as it is efficient and specific (Chattopadhyay et al. 2004).

In Egypt, several researches studied the biological control of destructive cotton pests such as the leaf worms, spiny and pink bollworms, using some Bacillus species (Abd-Elazeem et al. 2017). 
The aim of this study was to isolate bacterial isolates from the cotton plant and identify them then evaluated their pathogenic effect against the spiny bollworm, E. insulana. Moreover, it aimed to study the biological effects of the most affected isolates.

\section{Methods}

\section{Spiny bollworm rearing}

The SBW larvae used in this study were obtained from the mass rearing culture of bollworms. It had been reared on artificial diet for several generations away from any contamination of insecticides. This artificial diet was described previously by Amer (2015). The experiment was performed under controlled conditions in an incubator at $26 \pm 1{ }^{\circ} \mathrm{C}$ and $65 \pm 5 \% \mathrm{RH}$.

\section{Cotton sampling}

Different cotton plant samples (leaves, stems and roots) were collected from various areas of Sharkia governorate, Egypt. The collected samples were placed in clean plastic bags and transferred to the laboratory for the isolation steps. The plant material was identified by Dr. Samir Teleb, Lecture of taxonomy of higher plants, Botany Department, Faculty of Sciences. Voucher specimen of this material was deposited in a publicly available herbarium.

\section{Microbiological analysis \\ Bacterial isolation}

Plant samples were washed by tap water, followed by sterile distilled water. Each plant sample was cut into $2 \mathrm{~cm}$ long segments, using an aseptic sterile blade under the laminar flow hood and was allowed to dry. The cut surfaces of plant segments were placed in Petri plates containing Nutrient Agar (NA) media (Hi media, India). Each plant segment was inoculated in triplicate. Plates were then incubated at $30{ }^{\circ} \mathrm{C}$ for $48 \mathrm{~h}$. Colonies of different pigmentation and morphology were randomly selected from each plate and streaked on fresh NA plates as described above. The pure isolates were preserved in $20 \%$ glycerol at $-20{ }^{\circ} \mathrm{C}$ for other studies (Girlanda et al. 2001).

\section{Bacterial culture preparations}

Bacterial culture prepared by the broth inoculum was taken from plated material and developed in $250 \mathrm{ml}$ flasks, containing $50 \mathrm{ml}$ of the broth. Then the bacterial broth was cultured at $35{ }^{\circ} \mathrm{C}$ in an orbital shaker for 24 then $48 \mathrm{~h}$, shaking at $100 \mathrm{rpm}$.
Table 1 Pathogenicity of some bacterial isolates on newly hatched spiny bollworm larvae

\begin{tabular}{|c|c|c|c|c|c|}
\hline $\begin{array}{l}\text { Isolate } \\
\text { numbers }\end{array}$ & Isolates & $\begin{array}{l}\text { Mortality } \\
\%\end{array}$ & $\begin{array}{l}\text { Isolate } \\
\text { numbers }\end{array}$ & Isolates & Mortality \% \\
\hline 1 & CKR1 & 15 & 37 & CML2 & 40 \\
\hline 2 & CKR2 & 65 & 38 & CML3 & 70 \\
\hline 3 & CKR3 & 20 & 39 & CML4 & 20 \\
\hline 4 & CKR4 & 15 & 40 & CML5 & 15 \\
\hline 5 & CKR5 & 50 & 41 & CMS1 & 55 \\
\hline 6 & CKR6 & 45 & 42 & CMS2 & 30 \\
\hline 7 & CKL1 & 70 & 43 & CMS3 & 20 \\
\hline 8 & CKL2 & 75 & 44 & CMS4 & 65 \\
\hline 9 & CKL3 & 45 & 45 & CMS5 & 15 \\
\hline 10 & CKL4 & 15 & 46 & CMS6 & 10 \\
\hline 11 & CKL5 & 25 & 47 & CAR1 & 25 \\
\hline 12 & CKL6 & 95 & 48 & CAR2 & 55 \\
\hline 13 & CKS1 & 55 & 49 & CAR3 & 70 \\
\hline 14 & CKS2 & 45 & 50 & CAR4 & 20 \\
\hline 15 & CKS3 & 35 & 51 & CAL1 & 55 \\
\hline 16 & CKS4 & 15 & 52 & CAL2 & 60 \\
\hline 17 & CKS5 & 45 & 53 & CAL3 & 65 \\
\hline 18 & CTR1 & 90 & 54 & CAL4 & 15 \\
\hline 19 & CTR2 & 70 & 55 & CAL5 & 70 \\
\hline 20 & CTR3 & 75 & 56 & CAL6 & 15 \\
\hline 21 & CTL1 & 55 & 57 & CAS1 & 60 \\
\hline 22 & CTL2 & 45 & 58 & CAS2 & 10 \\
\hline 23 & CTL3 & 50 & 59 & CAS3 & 10 \\
\hline 24 & CTL4 & 75 & 60 & CAS4 & 20 \\
\hline 25 & CTL5 & 50 & 61 & CAS5 & 20 \\
\hline 26 & CTS1 & 25 & 62 & CAS6 & 30 \\
\hline 27 & CTS2 & 30 & 63 & CBR1 & 20 \\
\hline 28 & CTS3 & 15 & 64 & CBR2 & 65 \\
\hline 29 & CTS4 & 45 & 65 & CBL1 & 20 \\
\hline 30 & CMR1 & 65 & 66 & CBL2 & 90 \\
\hline 31 & CMR2 & 30 & 67 & CBL3 & 10 \\
\hline 32 & CMR3 & 55 & 68 & CBS1 & 80 \\
\hline 33 & CMR4 & 15 & 69 & CBS2 & 15 \\
\hline 34 & CMR5 & 75 & 70 & CBS3 & 95 \\
\hline 35 & CMR6 & 65 & Control & & 0 \\
\hline 36 & CML1 & 90 & & & \\
\hline
\end{tabular}

$\mathrm{C}=$ Cotton, $\mathrm{K}=$ Kafr abaza, $\mathrm{T}=$ Tahlet borden, $\mathrm{A}=$ Anshas albasal, $\mathrm{B}=$ Borden, $M=$ Met abo ali, $L=$ Leaf, $S=$ Stem, $R=$ Root

\section{Characterization of most potent bacterial isolate Characterization of isolated bacterial colony by light microscope}

Developed bacterial colonies were examined daily and the purified bacteria were identified to the species level whenever possible. The identification of bacterial genera and species was carried out by the help of the universally accepted keys for the characterization of the different 
Table 2 Virulence of the most affected isolates on different days old larvae of the spiny bollworm

\begin{tabular}{|c|c|c|c|c|c|c|c|c|}
\hline \multirow{3}{*}{$\begin{array}{l}\text { Bacterial isolates } \\
\text { number }\end{array}$} & \multicolumn{8}{|c|}{ Mortality \% } \\
\hline & \multicolumn{2}{|c|}{3 day-old larvae } & \multicolumn{2}{|c|}{5 day-old larvae } & \multicolumn{2}{|c|}{7 day-old larvae } & \multicolumn{2}{|c|}{10 day-old larvae } \\
\hline & After $48 \mathrm{~h}$ & After $96 \mathrm{~h}$ & After $48 \mathrm{~h}$ & After $96 \mathrm{~h}$ & After $48 \mathrm{~h}$ & After $96 \mathrm{~h}$ & After $48 \mathrm{~h}$ & After $96 \mathrm{~h}$ \\
\hline 12 & 0 & 90 & 0 & 50 & 0 & 50 & 0 & 30 \\
\hline 18 & 10 & 50 & 0 & 45 & 0 & 30 & 0 & 10 \\
\hline 6 & 0 & 10 & 0 & 10 & 0 & 10 & 0 & 10 \\
\hline 66 & 10 & 40 & 0 & 10 & 0 & 0 & 0 & 0 \\
\hline 70 & 0 & 10 & 0 & 10 & 0 & 10 & 0 & 10 \\
\hline Control & 0 & 0 & 0 & 0 & 0 & 0 & 0 & 0 \\
\hline
\end{tabular}

isolates. Morphology was based on colony shape, height and color of the colony, growth rate and margin characteristics Benson (1998).

\section{Molecular characterization (sequence of $16 \mathrm{~S}$ rRNA gene of DNA)}

Added $200 \mu \mathrm{l}$ of sample (liquid media that contain bacteria) in micro centrifuge tube and add $95 \mu$ water, $95 \mu \mathrm{l}$ solid tissue buffer (blue) and $10 \mu \mathrm{l}$ proteinase $\mathrm{K}$. Mix thoroughly and then incubate the tube at $55{ }^{\circ} \mathrm{C}$ for $2 \mathrm{~h}$. Mix thoroughly and centrifugation at $12,000 \times g$ for $1 \mathrm{~min}$. Transfer aqueous supernatant to a clean tube (300 ul). Add $600 \mathrm{ul}$ genomic binding buffer and mix thoroughly. Transfer the mixture to a zymo-spin ${ }^{\mathrm{TM}}$ IIC-XL column in a collection tube. Centrifuge $(\geq 12,000 \times g)$ for $1 \mathrm{~min}$. Discard the collection tube with the flow through. Add $400 \mu \mathrm{l}$ DNA pre-wash buffer to the column in a new collection tube and centrifuge at $(12.000 \times g)$ for $1 \mathrm{~min}$. Add $700 \mu \mathrm{lg}$-DNA wash buffer and centrifuge at $(12.000 \times g)$ for $1 \mathrm{~min}$. Empty the collection tube. Add $200 \mu \mathrm{l}$ g-DNA wash buffer and centrifuge at $(12.000 \times g)$ for $1 \mathrm{~min}$. Discard the collection tube. Add $30 \mu \mathrm{l}$ elution buffer, incubated for $5 \mathrm{~min}$ and then centrifuge at $(12.000 \times g)$ for $1 \mathrm{~min}$. The primers used were 27F AGA GTTTGATCMTGGCTCAG and 1492R CGGTTACCT TGTTACGACTT. Characterization was done at sigma scientific technical support laboratory Cairo, Egypt.

\section{Bioassay \\ Pathogenicity effect of 70 bacterial isolates on the newly hatched spiny bollworm larvae}

Pathogenicity of 70 isolated bacteria was tested against the newly hatched larvae of SBW as follow: One ml of each selected bacterial isolated broth was distributed on the surface of Petri-dishes ( $9 \mathrm{~cm}$ in diameter) containing $5 \mathrm{~g}$ of the artificial diet without antimicrobial agent and left until complete dryness. Twenty newly hatched larvae of SBW were transferred by a soft brush to the surface of treated diet in Petri-dishes then, they were covered by fine and soft paper below the glass cover. Other Petridish as a control were prepared containing the same diet but treated with one $\mathrm{ml}$ of sterile distilled water and left till dryness and an also twenty larvae were placed on each surface. Treated and control Petri-dishes incubated in an incubator at $26 \pm 1{ }^{\circ} \mathrm{C}$ and $65 \pm 5 \% \mathrm{RH}$. The treated and untreated larvae were transferred individually after $24 \mathrm{~h}$ from treatment to glass tubes $(2 \times 7 \mathrm{~cm})$ containing untreated diet $(4 \mathrm{~g})$. Tubes were plugged with absorbent cotton and incubated at the above-mentioned conditions. Larval mortality was recorded after two days of treatment.

\section{Pathogenicity of the most affected bacterial isolates on different day-old larvae of SBW}

Virulence of the most affected bacterial isolates (no. 12, 18, 36, 66 \& 70) against 3, 5, 7 and 10-day old larvae of the SBW were prepared as above. Then, they were fed on treated diet for $24 \mathrm{~h}$. Larval mortality was recorded after 48 and $96 \mathrm{~h}$ of treatment (El-Didamony et al. 2016).

\section{Biological effects of $B$. safensis on some biological aspects of SBW}

The latent effects of $B$. safensis on certain biological aspects of SBW; serial dilutions of $B$. safensis culture $\left(10^{-1}, 10^{-2}, 10^{-3}, 10^{-4}\right.$ and $\left.10^{-5}\right)$ were studied to provide the most suitable concentration on studying the biological effect. Artificial diet (5 g) without antimicrobial agent was placed in a Petri dish. One $\mathrm{ml}$ of B. safensis $10^{-5}$ concentration and one $\mathrm{ml}$ of water as control were distributed on the surface of diet and left till complete dryness. Twenty-five newly hatched larvae were transferred to the surface of each Petri-dish. Each treatment and control 


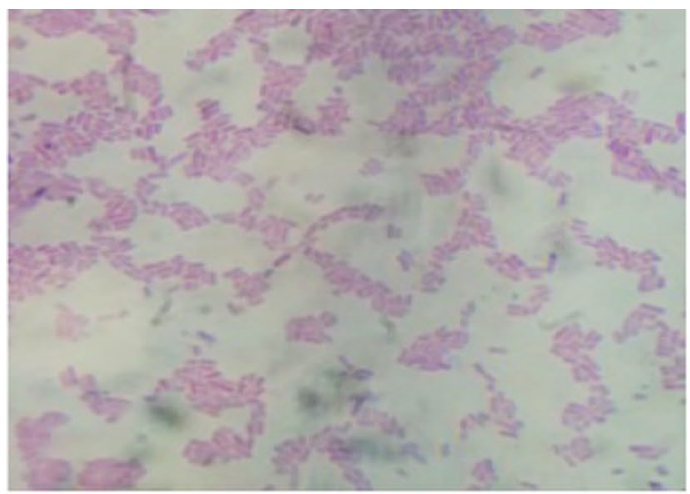

$\mathbf{a}$

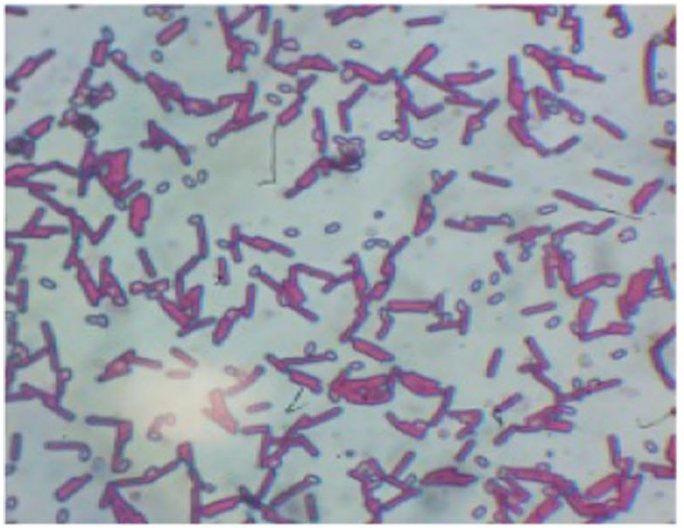

c

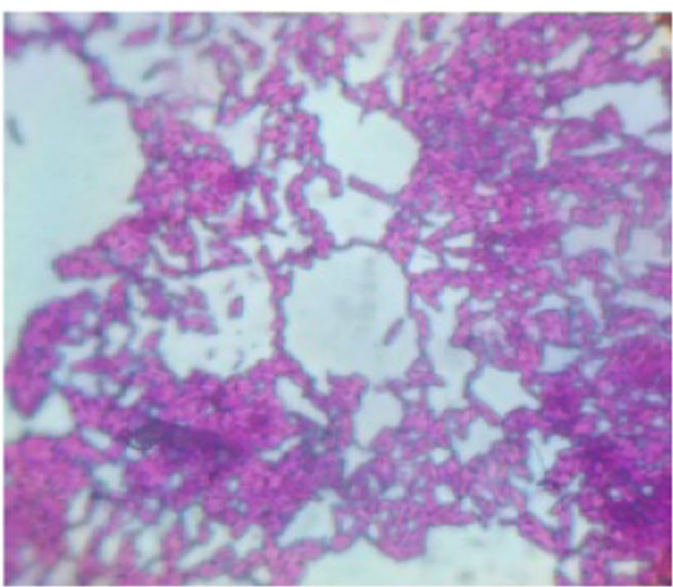

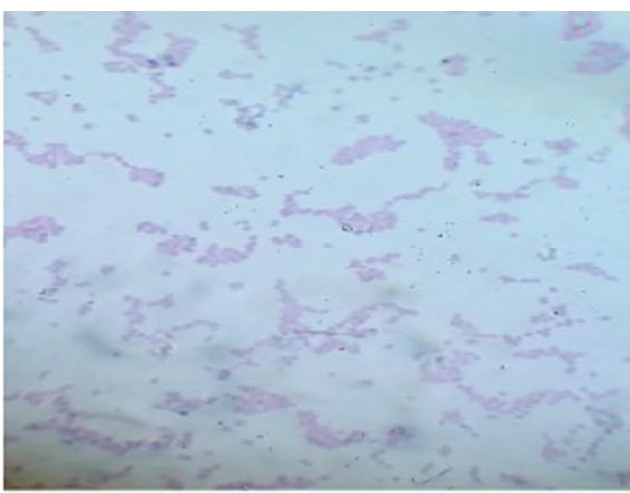

b

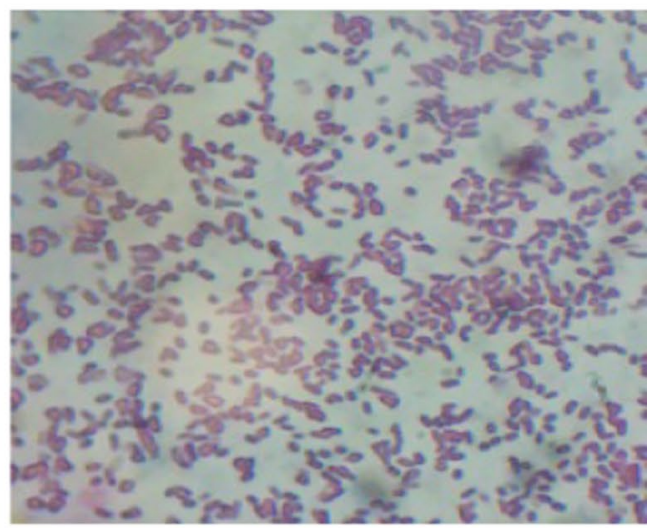

d

Fig. 1 Gram staining of the most effective bacterial isolates

were replicated 4 times. Treated and control Petri-dishes were covered by soft paper below their covers and placed in an incubator at standard conditions of $26 \pm 1{ }^{\circ} \mathrm{C}$ and $65 \pm 5 \% \mathrm{R} \mathrm{H}$. After $24 \mathrm{~h}$, the alive larvae were transferred to glass tubes $(2 \times 7 \mathrm{~cm})$ containing untreated diet, kept at the same previous conditions, and followed up daily till pupation. The pupae were transferred to clean tubes until adult emergence. The newly emerged moths of 


\begin{tabular}{|c|c|}
\hline Descripion & 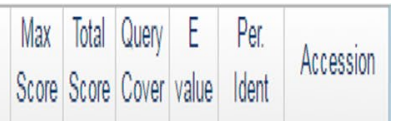 \\
\hline 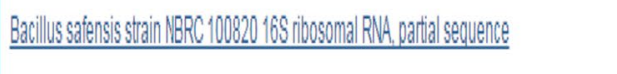 & 18101810 100\% $0.099 .80 \%$ N NR 113945.1. \\
\hline 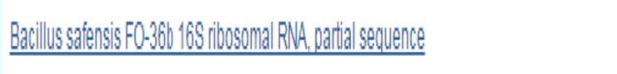 & $18101810100 \%$ 0.0 99:800\% 스 041794.1 \\
\hline 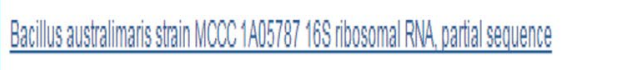 & $1799 \quad 1799900 \% 0.099 .59 \%$ NR 148787.1 \\
\hline 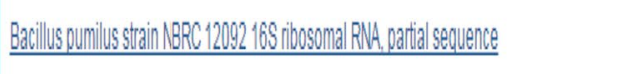 & 17991799 100\% $0.099 .599 \%$ NR 112637.1. \\
\hline 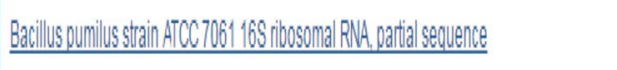 & $179917999100 \% 0.099 .599 \%$ NR 042224.1 \\
\hline 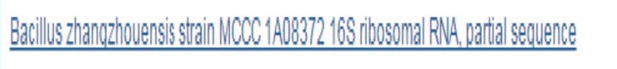 & $1794 \quad 1794 \quad 100 \%$ 0.0 $99.499 \%$ NR 148786.1 \\
\hline 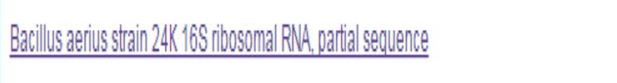 & 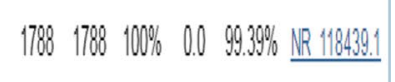 \\
\hline 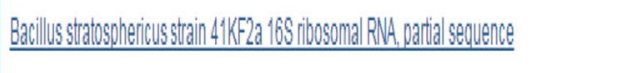 & $178817888100 \% 0.099 .399 \%$ NR 442336.1 \\
\hline 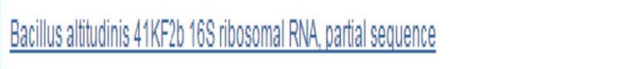 & $178891788900 \% 0.099 .399 \%$ NR 442337.1 \\
\hline 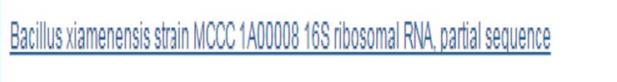 & $1783 \quad 1783100 \% \quad 0.099 .299 \% \underline{\mathbb{N R} 146244.1}$ \\
\hline 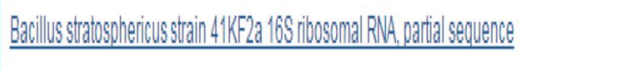 & $17831783100 \% \quad 0.099 .299 \% \underline{\mathbb{N R} 118441.1}$ \\
\hline 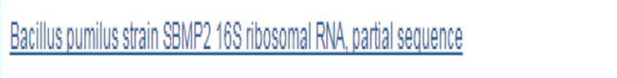 & 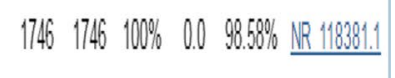 \\
\hline 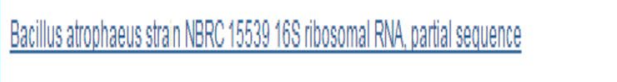 & 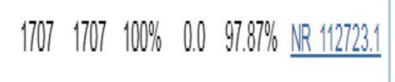 \\
\hline 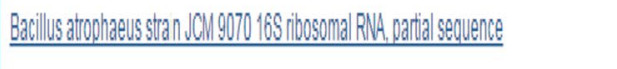 & $1705 \quad 1705 \quad 100 \% \quad 0.097 .87 \%$ NR 024689.1 \\
\hline 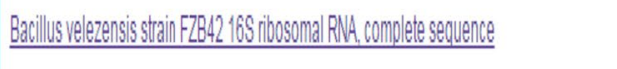 & $168801688800 \% \% 0.097 .57 \% \underline{\mathrm{NR} 075005.2}$ \\
\hline 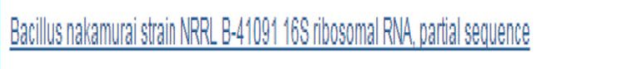 & $1688816088100 \%$ 0.0 97.57\% NR151889.1. \\
\hline 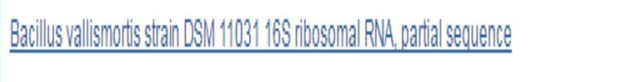 & $1688816888100 \% 0.097 .57 \%$ NR 026606.1 \\
\hline 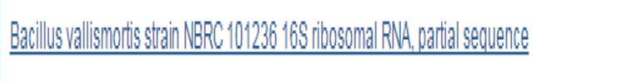 & $1680516805100 \%$ 0.0 $97.77 \%$ NR 113994.1 \\
\hline 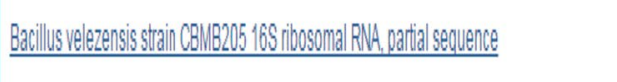 & 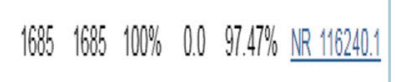 \\
\hline 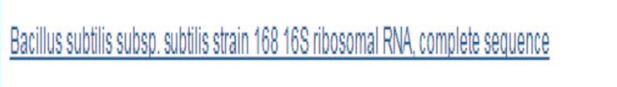 & $168831683100 \% 0.0997 .77 \% \underline{\underline{N R} 1027832}$ \\
\hline 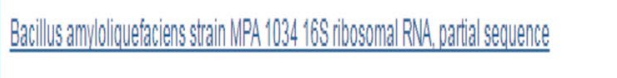 & $16631683100 \% 0.097 .77 \% \underline{\underline{N R} 177949.1}$ \\
\hline 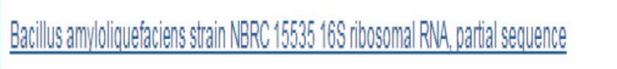 & 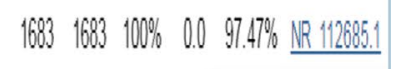 \\
\hline
\end{tabular}

Fig. 2 16S ribosomal RNA gene of Bacillus safensis and its similarity schedule

each treatment and control were sexed, placed in glass chimney cages for mating (5 pairs/cage) and replicated 4 times. Inside the cage, a piece of cotton wool previously soaked in $10 \%$ sugar solution was suspended to be renewed every $48 \mathrm{~h}$ for moths feeding. The cages were examined daily until death of moths. The number of eggs laid by females was counted, placed in clean glass jar and incubated under the same conditions until hatched. Main 
AGGCTGCTGCGCGCCTACACATGCACGTGCGAGCGGACAGAAGGAGAGCTTGCTCCCG GATGTTAGCGGCGGACGGGTGAGTAACACGTGGGTAACCTGCCTGTAAGACTGGGATA ACTCCGGGAAACCGGAGCTAATACCGGATAGTTCCTTGAACCGCATGGTTCAAGGATG AAAGACGGTTTCGGCTGTCACTTACAGATGGACCCGCGGCGCATTAGCTAGTTGGTGGG GTAATGGCTCACCAAGGCGACGATGCGTAGCCAACCTGAGAGGGTGATCGGCCACACT GGGACTGAGACACGGCCCAGACTCCTACGGGAGGCAGCAGTAGGGAATCTTCCGCAAT GGACGAAAGTCTGACGGAGCAACGCCGCGTGAGTGATGAAGGTTTTCGGATCGTAAAG CTCTGTTGTTAGGGAAGAACAAGTGCGAGAGTAACTGCTCGCACCTTGACGGTACCTAA CCAGAAAGCCACGGCTAACTACGTGCCAGCAGCCGCGGTAATACGTAGGTGGCAAGCG TTGTCCGGAATTATTGGGCGTAAAGGGCTCGCAGGCGGTTTCTTAAGTCTGATGTGAGA GCCCCCGGCTCAACCGGAGACGGTCATTGGGAAACTGGGAAGCTTGAGTGCACAAAAT GAAAGTGGAATTCCACGTGTACCCGTGAAATGCCTATAGATGTGGAGGAACACCAGTG GCGTAAGACGACTGTTCTGCTCTCTAAGCTTACGCTCACTAAGCCGAAATCTTTCAGAA CCAGAAGAGTCATCATATGACACTGGGGGGTCCCCCCCCCTTCTCCACGCAATTTCTAA CGGCTTCCCGGGGGGAATTCCCCCTCCCCCTTCTTGGGGGCCTACAGTGTTCCCACGTTT TCCCAAGGAGCCCCCCCCCGTGTGGGACCGCGGGGGGTTTTCCCATATAATACTTAAAA AAACGCGCCCGGGAGACGCCTTTTTTGCCCCCCAGAATATCCCCGAGAAAAGAGCGGT GGGGGCCCCTGCTAGTTTTAACCGGGGGGGGGGGCGGGGCCAGGAATATTTACCCCCC GGGGGTTTTTTTTGGTTGGTGGTGACCCCGGGGGAGGGAGGGGGGGAGAAAATTTTTCC CCCCCCCGCGGTGTTTTTTTTTTTCTCCCCCCCCAAAAAAAAAAAAAAAGATGTTATTTT TTTATCAACGCCACACAAAAAAACTCTCCTTTTCTCCCTCTCACCCACGCCGGGGCGGG GGGTGTGTTTTCCCTCTTTGAA

Fig. 3 Large subunit partial sequence of 165 ribosomal RNA of Bacillus safensis

parameters were estimated such as larvae and pupal durations, weight of full-grown larvae and pupae (oneday old) and pupation percent. The emergence percent and sex ratio were measured as percent of females from the total number of emerged adults. Fecundity (eggs' number) per female and fertility were calculated. In addition to female longevity as pre-oviposition, oviposition and post-oviposition periods and male longevity were determined.

\section{Statistical analysis}

Obtained results were analyzed to compare the mean of treated and control according to Little and Hills (1975) and CoStat computer program Cohort Software. P. O. Box 1149, Berkeley CA 9471 (CoStat program 2005).

\section{Results \\ Pathogenicity studies \\ Pathogenicity of 70 bacterial isolates against the newly hatched spiny bollworm larvae}

Pathogenicity of the isolates was screened against the newly hatched larvae of the SBW. Only 5 isolates (no. $12,18,36,66$ and 70 ) of them gave mortality $90 \%$ and more. The mortality percentages were 90, 95, 90, 90 and $95 \%$ for the isolates, respectively. While, the remaining isolates gave a mortality rate less than $90 \%$, represented by $92.85 \%$ of the total isolates (Table 1 ).

\section{Pathogenicity of the selected bacterial isolates on SBW different day-old larvae}

Results presented in Table 2 represent the efficacy of selected bacterial isolates (no. 12, 18, 36, 66 \& 70) against the different days old larvae of the SBW. The larval mortality was detected as follow: For the 3 day-old larvae, the highest mortality was $(90.00 \%)$ for the isolate number 12 . For the 5 day-old larvae, the highest larval mortality (50.00\%) was recorded for the isolates number 12 $\& 18$. However, for the 7 day-old larvae, the highest larval mortality $(50.00 \%)$ was recorded for the isolate number 12 . For the 10 day-old larvae, the highest larval mortality (30.00\%) was recorded for the isolate number 12 compared to $0.00 \%$ for the control. Therefore, the most effective isolate was the isolate no. 12 at all treatments.

\section{Characterization of most potent bacterial isolate Characterization of isolated bacteria by light microscope}

The gram staining of the most affected bacterial isolates on SPW larvae was done as shown in Fig. 1 which illustrated that all isolates were gram positive bacteria bacilli but the isolate n. 66 was coccobacilli. 


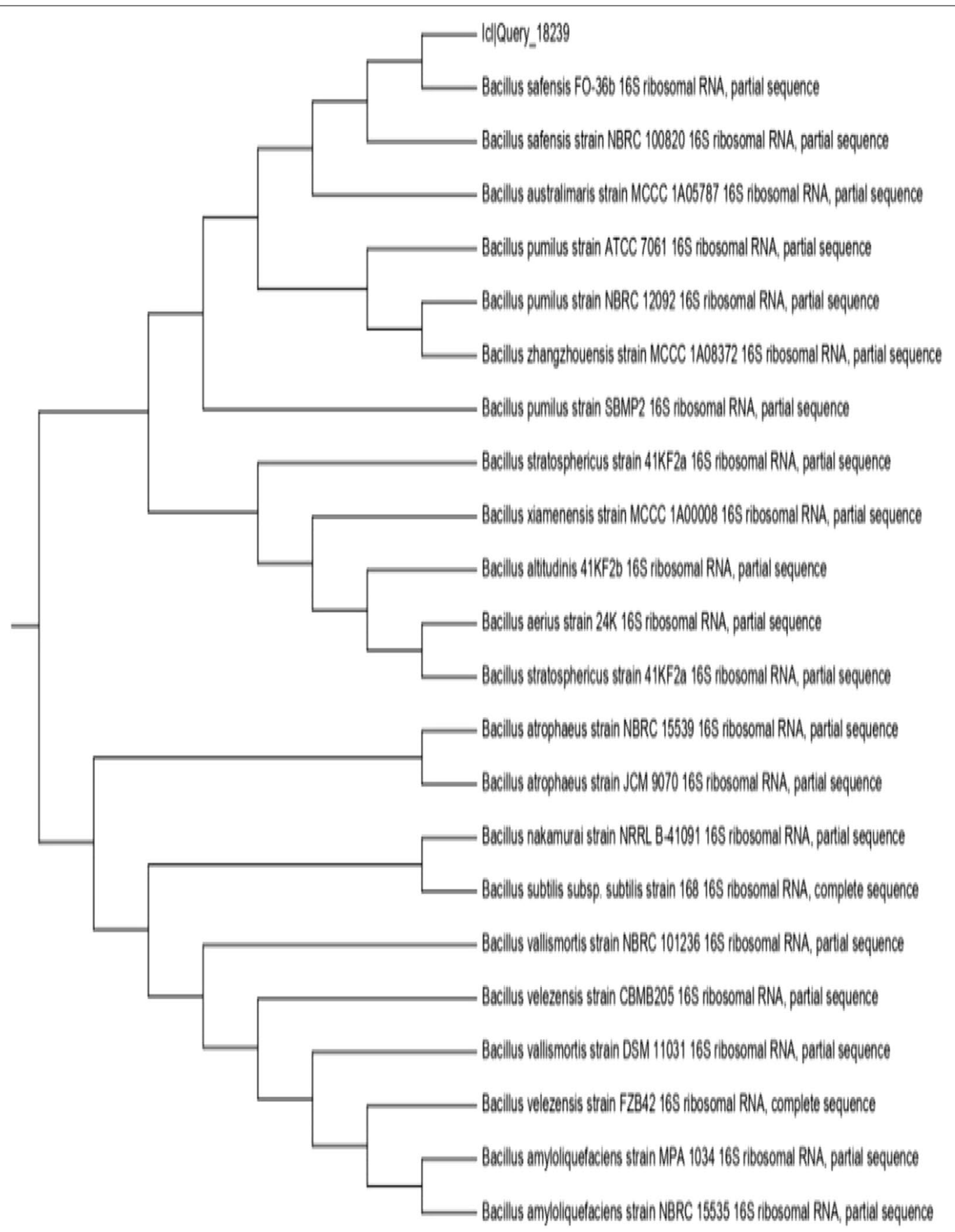

Fig. 4 Phylogenetic tree of Bacillus safensis compared to closely related organisms in GenBank

\section{Molecular characterization (sequence of 16S rRNA gene} of DNA)

From the previous illustrated identifications in Figs. 2, $3,4,5$, the most affected isolate n. 12 of the 70 isolates was identified as Bacillus safensis NBRC 100820 and took accession number MW281809.

\section{Biological studies}

Results presented in Table 3 showed that increasing the bacterial concentration caused an increase in mortality percentage of SBW newly hatched larvae. The highest larval mortality percentage was recorded with stock (100\%) after $96 \mathrm{~h}$ of treatment. The lowest larval mortality percentage recorded $30 \%$ with $10^{-5}$ concentration. 


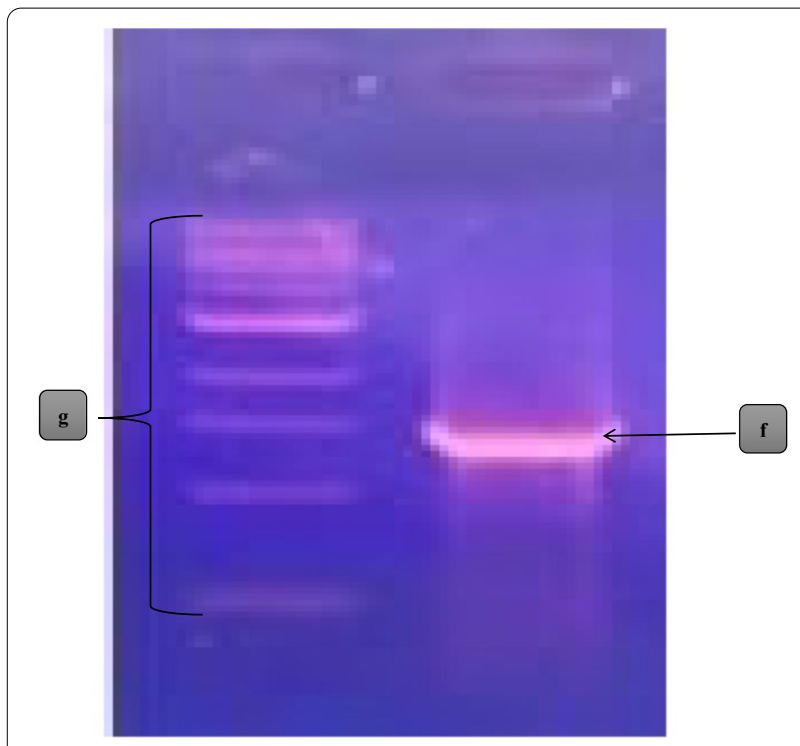

Fig. 5 PCR product of $16 \mathrm{~S} r \mathrm{RNA}$ region of Bacillus safensis bacteria on agarose gel, a isolates no. 12, b isolates no. 18, c isolates no. 6, d isolates no. 66, e isolates no. 70, f: Bacillus safensis (1500 bp), $\mathbf{g}$ Ladder $(10,000 \mathrm{bp})$

\section{Larval stage}

Larval mortality percentage of SPW was $52 \%$ after treated with B. safensis NBRC 100820, concentrated at $10^{-5}$, compared to $4.00 \%$ at the control. The results indicated that there was a highly significant difference between B. safensis NBRC 100820 and the control. It increased the larval duration, reaching 15.5 days compared to 13.50 days at the control. In addition, it decreased the larval weight $(0.069 \mathrm{~g} /$ larvae $)$ than $0.075 \mathrm{~g} /$ larvae at the control (Table 4).

\section{Pupal stage}

Data in Table 4 indicated that the effect of B. safensis NBRC 100820 isolate on pupal mortality percentage of SBW was significant than the control. The pupal mortality percentage was $12.0 \%$ for treated compared to $3.0 \%$ for the control and caused insignificant elongation of the pupal duration of SBW. The pupal duration was 10.5 days against 9.50 days at the control. It caused a significant effect on the SBW pupal weight which was $0.047 \mathrm{~g} / \mathrm{pupa}$ and $0.055 \mathrm{~g} / \mathrm{pupa}$ at the control.

\section{Adult stage}

Data presented in Table 5 showed that the fed of the SBW newly hatched larvae on the $B$. safensis NBRC 100820 isolate induced some effects on the adult stage. It caused a significant reduction in adult emergence which was $88.00 \%$ compared to $97.00 \%$ at the control and decreased the sex ratio (47\%: $53 \%$ ) for female: male compared to (49\%: 51\%) for the control. Pre-oviposition period of the SBW female was 2.5 days and 2.0 days at the control. According to the oviposition period, there was significant difference between female emerged from treated larvae with B. safensis NBRC 100820 isolate and the control. The oviposition period was 10.0 days at the treatment and 13.0 days at control. B. safensis NBRC 100820 isolate affected insignificantly the post-oviposition period of the SBW and recorded 4.0 days compared to 3.0 days for the control. A significant difference in female and male longevity were found between treatment (16.50 and 15.50 days, respectively) compared to control (18.00 and

Table 3 Pathogenicity of tested Bacillus safensis NBRC 100820 concentrations on newly hatched the spiny bollworm larvae

\begin{tabular}{|c|c|c|c|c|c|c|c|c|c|c|c|c|}
\hline \multirow[t]{3}{*}{ Bacterial isolates } & \multicolumn{12}{|c|}{ Mortality \% } \\
\hline & \multicolumn{2}{|c|}{ STOCK } & \multicolumn{2}{|l|}{$10^{-1}$} & \multicolumn{2}{|l|}{$10^{-2}$} & \multicolumn{2}{|l|}{$10^{-3}$} & \multicolumn{2}{|l|}{$10^{-4}$} & \multicolumn{2}{|l|}{$10^{-5}$} \\
\hline & $48 \mathrm{~h}$ & $96 \mathrm{~h}$ & $48 \mathrm{~h}$ & $96 \mathrm{~h}$ & $48 \mathrm{~h}$ & $96 \mathrm{~h}$ & $48 \mathrm{~h}$ & $96 \mathrm{~h}$ & $48 \mathrm{~h}$ & $96 \mathrm{~h}$ & $48 \mathrm{~h}$ & $96 \mathrm{~h}$ \\
\hline Bacillus safensis & 95 & 100 & 50 & 60 & 45 & 55 & 35 & 50 & 20 & 40 & 15 & 30 \\
\hline Control & 0 & 0 & 0 & 0 & 0 & 0 & 0 & 0 & 0 & 0 & 0 & 0 \\
\hline
\end{tabular}

Table 4 Effect of Bacillus safensis NBRC 100820 on immature stages of spiny bollworm

\begin{tabular}{|c|c|c|c|c|c|c|}
\hline \multirow[t]{2}{*}{ Treatments } & \multicolumn{3}{|l|}{ Larval stage } & \multicolumn{3}{|l|}{ Pupal stage } \\
\hline & Mortality \% & Period (days) & Weight (g) & Mortality \% & Period (days) & Weight (g) \\
\hline Bacillus safensis & 52.00 & $15.50 \pm 0.816$ & $0.07 \pm 0.0004$ & 12.00 & $10.50 \pm 0.204$ & $0.05 \pm 0.001$ \\
\hline Control & 4.00 & $13.50 \pm 0.480$ & $0.08 \pm 0.001$ & 3.00 & $9.50 \pm 0.315$ & $0.06 \pm 0.004$ \\
\hline Calculated T & 117.58 & 3.58 & 5.64 & 22.05 & & 13.86 \\
\hline$p$ & $<0.0001$ & 0.0117 & 0.0013 & $<0.0001$ & Ns & $<0.0001$ \\
\hline
\end{tabular}




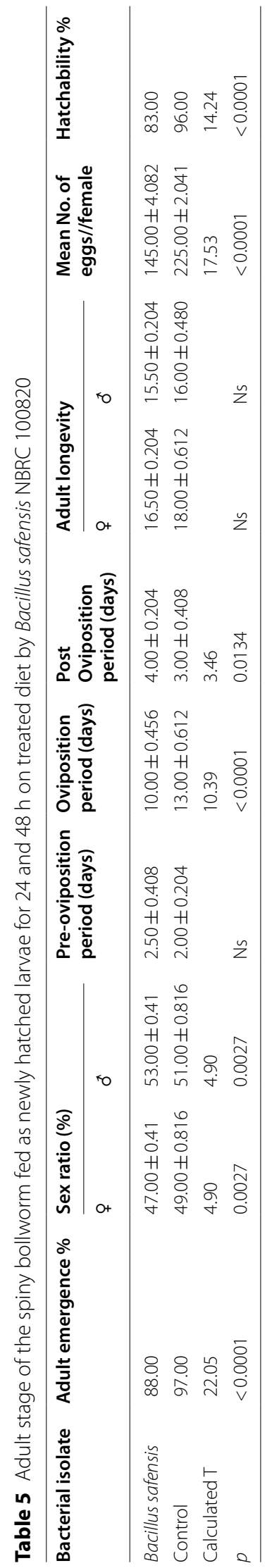


16.00 days, respectively). All moths that succeeded to emerge were able to lay a reduced number of eggs, varied significantly (145.00 eggs/female) than 225.00 eggs/ female at the control. According to hatchability percent, it reached $96 \%$ for untreated larvae and $83 \%$ for treated diet by this isolate.

\section{Discussion}

This study revealed that the isolated bacteria, identified as $B$. safensis, was characterized as gram positive bacteria and short bacilli as a result obtained by (Kothari et al. 2013). B. safensis can grow at $30^{\circ} \mathrm{C}$ and the best temperature to give the best effect was at $35^{\circ} \mathrm{C}$. These results are in harmony with different study where $B$. safensis can grow within temperature range of $10-50{ }^{\circ} \mathrm{C}$ (Satomi et al. 2006). This study showed that B. safensis isolated from the cotton plant had a toxic effect on SBW larvae reached (95\%) mortality percent. These results agree with many recent studies such as (Lateef et al. 2015) who proved that the larvicidal activity of $B$. safensis on the anopheline larvae reached to $\mathrm{LC}_{50}=42.19 \mu \mathrm{g} / \mathrm{ml}$. On the other hand, (Abd-Elazeem et al. 2017) also recorded the highly pathogenic effect of B. pumilus against the SBW larvae that reached $77.37 \%$ mortality percent.

Present results showed that $B$. safensis gave a latent effect on the different stages of the SBW. B. safensis, decreased the larval weight to $0.07 \mathrm{~g}$ than $0.08 \mathrm{~g}$ at the control and decreased the pupal weight to $0.05 \mathrm{~g}$ compared to $0.06 \mathrm{~g}$ at the control. The same result was reported by (El-Didamony et al. 2016) who showed that Paenibacillus xylaniticus decreased the larval weight to $0.07 \mathrm{~g}$ compared to $0.076 \mathrm{~g}$ of the control and decreased the pupal weight to $0.052 \mathrm{~g}$ compared to $0.056 \mathrm{~g}$ of the control.

Adult emergency percentage decreased as the effect of B. safensis to $88 \%$ than $97 \%$ at the control which is in harmony with (Abd-Elazeem et al. 2017) who recorded that B. pumilus decreased the adult emergency percentage by $80 \%$ than $100 \%$ at the control.

Deposition of eggs and its hatchability was also affected by $B$. safensis as it decreased the number of deposited eggs/females recording 145 eggs/female compared to 225 eggs/female at the control and also decreased the hatchability percentage to $83 \%$ compared to $96 \%$ at the control. These results totally agree with Hegab and Zaki (2012) who recorded a strong decrease in the number of deposited eggs/females reached to 149 eggs/females compared to 362 eggs/females of the control and a strong decrease in hatchability percentage reached $73 \%$ compared with $88 \%$ of the control when the larvae bio-assayed by Dipel 2x (B. thuringiensis).

\section{Conclusions}

It was concluded that 70 bacterial isolates were isolated from the cotton plant, one of these isolates identified using $16 \mathrm{~s}$ rRNA as B. safensis NBRC 100820. Therefore, it can be used in the biological and integrated pest management of E. insulana to reduce the using of insecticides which caused many problems in the ecosystem. Further field studies are needed.

\section{Abbreviations \\ SBW: Spiny bollworm; B. safeisis: Bacillus safensis; RH: Relative humidity; NA: Nutrient Agar; C: Cotton; K: Kafr abaza; T: Tahlet borden; A: Anshas albasal; B:} Borden; M: Met abo ali; L: Leaf; S: Stem; R: Root.

\section{Acknowledgements}

Thanks are due to Dr. Samah nour and Dr. Eman Mohammed Abd-ElAzeem, Plant Protection Research Institute, for his effort and helpful to carry out this experimental work. And Dr. Samir Teleb, Lecture of taxonmy of higher plants at botany department in faculty of science zagazig university for identification of the plant material used in the experimental work.

\section{Authors' contributions}

AAEl designed, analyzed and interpreted the data regarding the entomology and MFG designed, analyzed and interpreted the data regarding the microbiology. AAA performed all examination of the bacteria and spiny bollworm, and was a major contributor in writing the manuscript with AAEl and MFG. All authors read and approved the final manuscript.

Funding

No funding personal research.

\section{Availability of data and materials}

All data are available in the manuscript, and the materials used in this work are of high transparency and grade.

\section{Declarations}

Ethics approval and consent to participate

This article does not contain any studies with human participants or animals.

\section{Consent for publication}

Not Applicable.

\section{Competing interests}

The authors declare that they have no competing interests.

\section{Author details}

${ }^{1}$ Plant Protection Research Institute, Agricultural Research Center, Dokki, Egypt. ${ }^{2}$ Faculty of Science, Zagazig University, Zagazig, Egypt.

Received: 25 May 2021 Accepted: 14 August 2021

Published online: 23 August 2021 


\section{References}

Abd-Elazeem EM, El-Sayed AAA, Amer AEA (2017) Toxicity and biological effects of bacterial isolates on American bollworm, Helicoverpa armigera (Hubner) and spiny bollworm, Earias insulana (Boisd.). J Plant Prot Path Mansoura Univ 8(8):79-383

Amer AEA (2015) Economic artificial diets for rearing spiny bollworm, Earias insulana (Boisd.) (Lepidoptera: Noctuidae). J Plant Port and Path Mansoura Univ 6(3):527-534

Benson HJ (1998) Microscope slide techniques (bacterial morphology). Microbiological applications laboratory manual in general microbiology, 7th edn. California St. Louis Missouri, Boston, pp 49-70

Chattopadhyay A, Bhatnagar NB, Bhatnagar R (2004) Bacterial insecticidal toxins. Crit Rev Microbiol 30:33-54

El-Didamony M, El-Sayed AAA, Ali AAEL (2016) Toxic and biological control of some endophytic bacteria on the spiny bollworm, Earias insulana (Boisd.). The Eleventh International Environmental Conference, Faculty of Science, Zagazig University, pp 407-421

Girlanda M, Perotto S, Moenne-Loccoz Y, Bergero R, Lazzari A, Defago G (2001) Impact of bio control Pseudomonas fluorescens $\mathrm{CHAO}$ and a genetically modified derivative on the diversity of culture-able fungi in the cucumber rhizosphere. Appl Environ Microbiol 67:1851-1864

Glare TR, O'Callaghan M (2006) Bacillus thuringiensis: biology ecology and safety. Wiley, Chichester, p 350

Hegab MEA, Zaki AAA (2012) Toxicological and biological effects of bacteria, Bacillus thuringiensis kurstaki on Pectinophora gossypiella (Saund.) and entomopathogenic fungi, Beauveria bassiana on Earias insulana (Boisd.). J Plant Port and Path Mansoura Univ 3(3):289-297

Ishag AESA, Abdelbagi AO, Hammad AMA, Elsheikh EAE, Elsaid OE, Hur $J$ H, Laing MD (2016) Biodegradation of chlorpyrifos, malathion, and dimethoate by three strains of Bacteria isolated from pesticide-polluted soils in Sudan. J Agric Food Chem 64:8491-8498

Kothari WV, Kothari RK, Kothari CR, Bhatt VD, Nathani NM, Koringa PG, Joshi CG, Vyas BRM (2013) Genomic sequence of salt-tolerant Bacillus safensis strain
VK, isolated from saline desert area of Gujarat. India Genome Announc 2:e00337-14

Lateef A, Ojo SA, Akinwale AS, Azeez L, Gueguim-Kana EB, Beukes LS (2015) Biogenic synthesis of silver nanoparticles using cell-free extract of Bacillus safensis LAU 13: antimicrobial, free radical scavenging and larvicidal activities

Little TM, Hills FJ (1975) Statistical method in agriculture research available from U. C. D. Book store, University of California, Davis, p 241

Nada AM, Ragab MG, El-Lebody KA (2010) Occurrence and movements of the spiny bollworm, Earias insulana (Boisd.) within some it's host plants. J Plant Protect Pathol 1(8):635-646

Roohi A, Ahmed I, Khalid N, Iqbal M, Jamil M (2014) Isolation and phylogenetic identification of halotolerant/halophilic bacteria from the salt mines of Karak, Pakistan. Int J Agric Biol 16:564-570

Satomi M, Duc MTL, Venkateswaran K (2006) Bacillus safensis, isolated from spacecraft and assembly-facility surfaces. Int J Syst Evol Microbiol $56: 1735-1740$

Wahla AQ, labal S, Anwar S, Firdous S, Mueller JA (2019) Optimizing the metribuzin degrading potential of a novel bacterial consortium based on Taguchi design of experiment. J Hazard Mater 366:1-9

Wang YH, Chen L, An X, Jiang J, Wang Q, Cai L, Zhao X (2012) Susceptibility of adult Trichogramma nubilale (Hymenoptera: Trichogrammatidae) to selected insecticides with different modes of action. Crop Prot 34:76-82 Yongqiang L, Xiangying L, Chao Z, Feng L, Wei M (2016) Toxicity of nine insecticides on four natural enemies of Spodoptera exigua. Sci Rep 6:39060

\section{Publisher's Note}

Springer Nature remains neutral with regard to jurisdictional claims in published maps and institutional affiliations.

\section{Submit your manuscript to a SpringerOpen ${ }^{\circ}$ journal and benefit from:}

- Convenient online submission

- Rigorous peer review

- Open access: articles freely available online

- High visibility within the field

- Retaining the copyright to your article

Submit your next manuscript at $\boldsymbol{\nabla}$ springeropen.com 